\title{
Heiner Müller jako rizoma
}

\author{
Barbora Liška
}

\begin{abstract}
Abstrakt
Cílem studie je představit koncept rizomatu Gillese Deleuze a Félixe Guattariho jako jeden ze základních poetických principů v díle východoněmeckého básníka světového významu Heinera Müllera (1929-1995). Autorka studie poukazuje na několika vybraných př́kladech, čím je dílo a tvưrčí strategie Heinera Müllera rizomatické a proč může být při analýze konkrétního Müllerova textu užitečné vnímat jej v souvislostech s jinými Müllerovými texty. Vzhledem k tomu, že tvorba Heinera Müllera je poměrně na okraji zájmu českého teatrologického výzkumu, měla by studie sloužit jako úvodní vhled do dané problematiky.
\end{abstract}

\section{Klíčová slova}

Heiner Müller, Gilles Deleuze, Félix Guattari, rizoma, postdramatické divadlo

\begin{abstract}
The aim of the study is to discuss the concept of rhizome, sensu Gillese Deleuze and Félix Guattari, as one of the basic poetic principles within the works of the world-wide known East German poet Heiner Müller (1929-1995). Using several selected examples, I trace the rhizo-matic quality of Müller's works and his creative strategy. I am also looking at how this quality can be important with regard to individual texts in their connection with other Müller's texts. Taking into account that analysis of Müller's works is somewhat peripheral in theatre studies, so the present article might serve as an introduction to the topic.
\end{abstract}

\section{Key words}

Heiner Müller, Gilles Deleuze, Félix Guattari, rhizome, postdramatic theatre 
Warum sterben die kleinen Leute?

Was haben die großen getan?

Otázka

[Proč umírají malí lidé?

Co učinili ti velcî?]

Heiner Müller (1998a: 61)

Východoněmecký básník a divadelník Heiner Müller u nás nepatří k autorům nejpřekládanějším ani nejinscenovanějším. Podle databáze Institutu umění - Divadelního ústavu byl v Česku od roku 1993 uveden celkem devětkrát ${ }^{1}$ a vydány byly pouze dvě antologie ${ }^{2}$ překladů Müllerových nejznámějších pozdních divadelních textů, Cementem (Zement, 1972) počínaje a Snovým textem (Traumtext, 1995) konče. Ačkoliv je recepce tohoto autora v českém divadelním i teatrologickém kontextu minimální, patří k tvưrcům, kteří v druhé polovině 20. století tvořili inovativní linii divadla, kriticky nakládali se zaužívanými uměleckými postupy a umožnili tak vůbec uvažovat o tvůrčích strategiích psaní pro divadlo i divadelní tvorby nového paradigmatu, které Hans-Thies Lehmann označil jako postdramatické. Dalo by se říci, že Müller patří k těm tvůrcům, kteří ve své době ovlivnili chápání divadla v celé jeho šíři. Ačkoliv se do dějin německého divadla zapsal hlavně jako básník a dramatik, působil i jako dramaturg, později jako činoherní a operní režisér, a kromě toho, pokud měl příležitost, formuloval své výstupy v médiích bez nadsázky jako filosoficko-estetické statě na různorodá témata spojená s divadelní a dramatickou ${ }^{3}$ tvorbou. V německé teatrologii je Müller často považován za největšího divadelníka a básníka po Bertoltu Brechtovi.

Cílem této studie je zakotvit několik úvah o Heineru Müllerovi v českém teatrologickém diskurzu. ${ }^{4}$ Domnívám se, že se jedná o jednu z postav evropských dějin divadla,

1 Šesti inscenátory jsou etablovaní divadelní tvưrci (Vladimír Morávek, Tomáš Svoboda, Dušan D. Pařízek, Jiří Honzírek, Michal Hába a Jiří Pokorný) a ve třech případech jde o studentské projekty DAMU a JAMU. Osobně vím ještě o dvou nezávislých jednorázových projektech někdejších studentů JAMU Barbory Chovancové a Jakuba Lišky, kteří vytvořili site-specific performance Müllerova triptychu Zpustlý břeh Materiál Médea Krajina s Argonauty (2016) a divadelního textu Hamlet-stroj (2018).

2 V prvním případě jde o pět překladů Josefa Balvína z roku 1982 (MÜLLER 1982) a v druhém o tři překlady publikované v roce 1998 (MÜLLER 1998b) pod pseudonymem K. R. Jilská s intencí Balvínovy překlady divadelních textů Hamlet-stroj, Pověreni a Kvartet revidovat (texty Shakespearưv Titus Andronicus: Anatomie a komentár a Hérakles 5 do této sbírky zařazeny nebyly). Mimo tyto dvě antologie existují ještě jednotlivé překlady textů Zpustlý břeh Materiál Médea Krajina s Argonauty, Popis obrazu (dokonce ve dvou verzích), Berlín: smrt Germánie, Cement, Ženská komedie a texty Silnice na Volokolamsk I, II a III, dostupné v agentuře Dilia.

3 Slovo „drama“ je zde užito jako obecné označení literárního žánru s vědomím toho, že forma dramatu se nejen v Müllerově tvorbě, ale i u jiných autorů rozvolňuje natolik, že nenaplňuje téměř v žádném ohledu konvenční představu o dramatickém textu založeném na principu reprezentace, již nabízí např́íklad Manfred Pfister (PFISTER 2000). Později se pro dramata tohoto nového paradigmatu ujímá pojem Gerdy Poschmann divadelní text, který v této studii budu k označení Müllerových konkrétních pozdních textů, v nichž opouští dramatickou formu, také užívat (POSCHMANN 1997).

4 V češtině doposud nevznikla žádná odborná studie věnovaná tvorbě Heinera Müllera. Čtenář je v př́ipadě zájmu o tuto tematiku odkázán výhradně na německojazyčné a anglickojazyčné zdroje. 
která může napomoci hlubšímu pochopení paradigmatu divadelní postmoderny a tím i nalezení kořenů současné divadelní estetiky, jež klade, s ohledem na vývoj technologií a médií, zase úplně jiné, nové výzvy než postmoderní dekonstrukce a decentralizace pozice textu v divadle. Jedná se tedy dle mého názoru o příklad tvůrce, $\mathrm{v}$ jehož díle lze identifikovat ozvuky inovativního divadla 2. poloviny 20. století a demonstrovat na něm teatrologické a kulturologicko-filosofické koncepty, jako je např́íklad Derridova dekonstrukce, Barthesova smrt autora, principy procesuality a performativity textu či v neposlední řadě koncepce divadelního textu Gerdy Poschmann. ${ }^{5}$

Perspektiva, kterou se zde pokusím nabídnout, není v žádném případě všezahrnující. Osobnost Heinera Müllera, o níž v německé, ale i anglosaské teatrologii existuje nespočet publikací, jež nabízejí množství různých přístupů a konceptuálních uchopení jeho tvůrčích strategií i konkrétních děl, představuje tak široké badatelské pole, že jej nelze obsáhnout v rámci jedné studie. Mým cílem je poukázat na poetický princip rizomatičnosti jako na teoretický koncept a metodologický nástroj, jehož prostřednictvím lze Müllerovo zdánlivě nehierarchizovatelné literární (dramatické, básnické i prozaické) dílo, které jako by do sebe jako černá díra pohlcovalo starší texty literárního kánonu, sebe sama i svého autora, pozitivně vymezit a paradoxně systémově uchopit - a to jako a-hierarchii, jako rizoma. Tvorbu Heinera Müllera lze samozřejmě nazírat a hierarchizovat tradičními literárněvědnými koncepty, jako jsou tvưrčí období, literární žánr nebo striktní rozdělení autora jakožto autority a jeho díla jakožto produktu tvůrčího procesu. A-hierarchie rizomatu naopak umožňuje všimnout si těch interpretačních možností, které Müllerovo dílo poskytuje a které př̀ tradiční kategorizaci zůstanou skryté, jelikož i sám autor se klasickým interpretačním postupům, například distinkci tvůrčích období v jeho díle, vzpírá.

Rizomatičnost lze tedy chápat jako jeden z charakteristických rysů Müllerovy tvorby a zároveň jako jeden z hlavních klíčủ k porozumění, jak na Heinera Müllera nazírat at̉ už z pohledu inscenátora, badatele, který se rozhodne zaměřit na konkrétní oblast Müllerova díla, nebo studenta, který se pokouší analyzovat některý z Müllerových formálně rozvolněnějších textů. Rizomatický princip lze chápat jako logiku tvorby, kterou se autor Heiner Müller řídí. Nutno přitom podotknout, že čtení Heinera Müllera prizmatem konceptu rizomatu není originálním př́ístupem: v německé teatrologii je Müller s tímto i s jinými poststrukturalistickými koncepty bytostně spjat, jakkoli zřejmě neexistuje studie, která by komplexně pojmenovávala, proč tomu tak je. Spíše se zdá, že německá teatrologie považuje produktivnost těchto teoretických konceptů pro porozumění Müllerovu dílu za axiom, který není potřeba př́lišs vysvětlovat. ${ }^{6}$ Na úvod je ještě důležité dodat, že nahlížení díla Heinera Müllera pomocí konceptu rizomatu není všespásné, respektive že perspektiva rizomatu nemá potenciál rozkrýt všechna důležitá témata, která jsou s tvorbou Heinera Müllera spjata; např́klad se to týká

5 Jednotlivé různorodé aspekty Müllerovy tvorby jsou podrobně popsány v obsáhlé příručce o Heineru Müllerovi Heiner Müller Handbuch Leben-Werk-Wirkung z roku 2003, kterou sestavili Hans-Thies Lehmann a Patrick Primavesi (LEHMANN a PRIMAVESI 2003).

6 Metaforu rizomatu zmiňuje v souvislosti s Heinerem Müllerem explicitně Hans-Thies Lehmann ve své studii „Raum-Zeit“ (LEHMANN 1982). 
reflexe marxistické a kapitalistické ideologie v jeho díle, témat společenské emancipace, revoluce a utopie nebo vztahu Müllerovy tvorby k mýtu a ke kánonu (LEHMANN a PRIMAVESI 2003). Účelem této studie je však s ohledem na kontext dosavadního nepříliš rozsáhlého českého teatrologického bádání o Müllerovi poukázat na to, že může být nápomocné, či dokonce žádoucí, vnímat jeho texty ve vzájemném propojení, nebot tak je možné objevit poznatky a souvislosti, které by při izolovaném pohledu na konkrétní text mohly uniknout.

\section{Rizoma}

Rizoma je koncept užívaný Gillesem Deleuzem a Félixem Guattarim k postižení odlišného modelu reality, subjektivity, poznávání a vypovídání, jež je - v opozici k myšlení sledujícímu logiku jednoduše binárně se dělícího, vždy k jednotícímu, centrálnímu kmeni se sbíhajícího větvení - založeno na představě nehierarchizované, a-centrální, ne-transcendentní, v sobě imanentně spočívající sítě či spleti multiplicitních spojení. (MATONOHA 2017: 77)

Delleuzova a Guattariho filosofická esej Rhizom byla poprvé vydána v roce 1976 a tři roky na to se stala úvodní kapitolou extravagantní knihy Tisíc plošin (DELEUZE a GUTTARI 2010), která představuje navazující díl antologie studií Schizofrenie a kapitalismus. Společně pak tyto dva filosofické spisy tvoří dvousvazkové dílo nazvané AntiOidipus. Kniha Tisíc Plošin je sama o sobě napsána rizomatickým zpo̊sobem, který se vzpírá pravidlům hierarchie, kauzality a linearity, tedy pravidlům, kterým knihy (knihy s uzavřeným fikčním světem konstruovaným na principu reprezentace) zpravidla podléhají. Müllerových Tisic plošin se tak dá chápat jako originální ztělesnění postmoderního stylu myšlení v podobě knihy (HAUER 2002: 177).

$\mathrm{V}$ českém výkladovém slovníku poststrukturalistických teorií a konceptů $\mathrm{Za}$ (de)konstruktivismem Jana Matonohy z roku 2017 není heslová stat pojednávající rizoma postavena pouze na originální koncepci Deleuzova a Guattariho rizomatu, ale pracuje i s její recepcí v českém literárněvědném kontextu. ${ }^{7}$ Vzhledem k tomu, že je koncept rizomatu již v české literární vědě na základě konsenzu tímto způsobem ukotven, rozhodla jsem se $\mathrm{v}$ této studii terminologický aparát nepřejímat z původní filosofické eseje Rhizom, ale právě z Matonohova výkladu. ${ }^{8}$ Esej Rhizom totiž nelze číst jako přesně definovaný konceptuálně-metodologický nástroj, který by bylo možné v rámci analýzy bezezbytku

7 Autor hesla cituje literárního vědce Zdeňka Hrbatu a literární teoretičky Danielu Hodrovou a Martinu Mašínovou.

8 Na okraj je nutné podotknout, že Deleuze s Guattarim nenabízejí alternativu stávajícího uspořádání reality. Inspirativní je na jejich konceptu rizomatu právě (a možná pouze) to, že odhaluje principy logocentrického chápání světa, které může být do velké míry limitující a nedůvěryhodné o to více, když máme již i mimo umění žitou zkušenost také se systémy, které nejsou strukturovány hierarchicky a nevztahují se k žádnému jednotícímu centru. Asi nejbanálnějším př́íkladem takového systému, s nímž se v každodenním životě setkáváme, je internetové prostředí globální počítačové sítě World Wide Web, která funguje na principu hypertextu, tedy nelineárního strukturování textu, který je skrze hypertextové odkazy propojen s nespočetným množstvím dalších textů. 
aplikovat, ale je třeba jej coby návrh ,jiné“ logiky či perspektivy myšlení při použití vždy znovu interpretovat (či použít již existující interpretaci, jako zde činím já).

Rizoma tedy může být definováno jako netranscendentni, v sobě imanentni, nehierarchizovaná splet či sît bez jednoticího centra, pro niž Deleuze a Guattari volí nejprve metaforu stroje (Anti-Odipus) a posléze metaforu kořenového systému oddenku (Tisíc plošin) (MATONOHA 2017: 77). Při aplikaci konceptu rizomatu na dílo a tvorbu Heinera Müllera jsou podle Matonohy stěžejní tyto jeho vlastnosti: 1) Nazírání autora coby subjektu v rizomatu zaniká, nebở je zde pojímán pouze jako dočasně jednotící koncept díla, který není totožný s autorem jakožto historickou osobou. 2) Rizoma nefunguje na principu reprezentace, a proto se v něm mění i pojetí textu. 3) Ten je součástí reality v rámci rizomatických propojení, jimiž do ní sám vstupuje a intervenuje, stejně jako je jí sám proměňován. 4) Rizoma představuje neredukovatelnou heterogennost a nepřevoditelnost na vyšší jednotící rovinu, kterou by mohla být například sémantická jednoznačnost jednotlivých textů. 5) Rizoma, skládající se z nekonečného množství částí, se štěpí dovnitř, skrze rozlišení na množství jedinečných podrovin a singularit, přičemž tato mnohost není automaticky k dispozici a je nutno ji nejprve odkrýt ${ }^{9}$ (MATONOHA 2017: 78).

Těchto pět rysů rizomatu se nyní pokusím přiblízit na př́ikladech Müllerovy literární tvorby, konkrétně na jeho pozdních divadelních textech. Ještě předtím však udělám krátkou odbočku k tomu, proč je vůbec relevantní na Heinera Müllera prizmatem koncepce rizomatu nazírat, a čím to je, že je to vůbec možné.

\section{Müller a poststrukturalismus}

V případě Heinera Müllera máme co dočiněnís velmi intelektuálním autorem a pečlivým čtenářem nejen kánonu umělecké literatury (mimo jiné Sofokla, Shakespeara, Hölderlina, Lessinga, Artauda či Brechta), ale i filosofie, a to i té z jeho pohledu soudobé, poststrukturalistické. Je až překvapující, jak se koncept rizomatu a tvorba Heinera Müllera vzájemně překrývají. Snad je to tím, do jaké míry je Müllerovo myšlení, jeho tvưrčí prŕstupy, formy i témata, poznamenáno dobovými intelektuálními tendencemi, zejména francouzským poststrukturalismem. Doklad o sepjetí myšlení francouzských poststrukturalistů (především Michela Foucaulta) a postmodernistů (především Gillese Deleuze a Félixe Guattariho) na jedné straně a Heinera Müllera na straně druhé nabízí Hans-Thies Lehmann ve svém článku „Raum-Zeit“, vydaném v literárním a kulturním časopise Text + Kritik, jehož 73 . číslo ${ }^{10}$ je věnováno právě Heineru Müllerovi:

9 To, že není mnohost automaticky k dispozici, interpretuji tak, že není na první pohled zjevná. V př́ípadě textů Heinera Müllera se to ukazuje na graficky přiznaném i nepřiznaném citování vlastních textů či textů jiných autorů, viz dále.

10 Toto müllerovské číslo časopisu Text + Kritik (ARNOLD 1982) lze chápat jako jednu z prvních obsáhlejších reflexí autora v literární vědě a teatrologii. V roce 1997 bylo toto číslo navíc rozšířeno o druhé vydání (ARNOLD 1997) s dalšími studiemi, jejichž autoři se věnují Müllerovi již s vědomím, o jak důležitou osobnost německého divadla se jedná. 
Souvislosti existují na první pohled: Müllera ve Francii recipovali významní teoretikové, byl překládán, uznáván. Gilles Deleuze patří k jeho pozorným čtenářům [...]. Stejně tak i Müller recipoval francouzské autory jako např́klad Foucaulta, Baudrillarda a Lyotarda, přičemž mimo jiné v př́ípadě jeho textů Gundling a Hamlet-stroj lze jasně pozorovat, že jejich autorovi nebyla Foucaultova „analýza šílenství“ či jeho pojem „vyloučení“ z Řádu diskurzu zcela neznámá [...]. (LEHMANN 1982: 72)

Tento Lehmannův text vyšel v roce 1982 a lze jej tak zařadit do období první vlny podrobné reflexe té části Müllerovy tvorby, kterou dnes chápeme jako emblematickou pro pojem postdramatické divadlo. Není proto náhodou, že Lehmann opírá svou poetiku Postdramatického divadla do velké míry právě o Müllerovu tvorbu. Lehmann konstatuje, že v jeho textech lze sledovat vliv francouzských filosofů nejen ve formě užívání stejných pojmů, ${ }^{11}$ ale že jde především o uvažování ve stejném řádu postmoderní filosofie, kterou se Müller ve své tvorbě inspiruje. Jinými slovy, kromě toho, že se pojem „rizomatický“ objevuje ve spojitosti s Müllerovou tvorbou na metarovině, v literárněvědném a teatrologickém diskurzu, rizomatické uvažování lze spatřovat i v samotném Müllerově díle. Úvodním příkladem budiž neuskutečněný projekt rakouského režiséra a blízkého Müllerova přítele Josepha Szeilera (*1948). ${ }^{12}$ V období nové postsocialistické éry Berliner Ensemble, kde Müller po sjednocení Německa působil jako jeden z pěti dosavadních ředitelů, ${ }^{13}$ vznikl nápad uspořádat nepřetržitou týdenní divadelní událost s názvem Jenseits des Todes ( $\mathrm{Z}$ druhé strany smrti), ${ }^{14} \mathrm{v}$ rámci

11 Např. pojem „stroj přáni“ (Deleuze a Guattari) jako jeden z odkazů v názvu snad nejznámějšího Müllerova divadelního textu Hamlet-stroj (1977).

12 Josef Szeiler patř́i k divadelním tvưrcům, na které je z dnešní perspektivy pohlíženo jako na první experimentátory s kategoriemi divadelního díla, jako jsou text, čas, prostor a tělo, a jako na první vlaštovky redefinice a dehierarchizace jednotlivých elementů divadla, s čímž souvisí také decentralizace pozice textu v divadelní tvorbě. Tvůrčí styl Szeilerovy divadelní skupiny Theater Angelus Novus, založené roku 1981 ve Vídni, patří také k těm, o něž se opírá Hans-Thies Lehmann ve svém eseji Postdramatické divadlo a jehož chápaní zejména prostoru a času se otisklo do představy, co divadlo dekonstrukce, dehierarchizace a delogocentrismu vlastně znamená. Josef Szeiler není v česko-slovenském kontextu tak známý jako jeho „postdramatičtí“ souputníci Robert Wilson, Frank Castorf nebo Jerzy Grotowski, nicméně jeho důležitost pro tuto studii spočívá v jeho bytostném sepjetí s o něco starším dramatikem a básníkem Heinerem Müllerem. Szeiler se s Müllerem osobně seznámil v Berlíně, kde od roku 1976 do roku 1979 pracoval jako asistent režie ve Volksbühne u Benno Bessona. Poté, co se vrátil zpátky do Vídně, realizoval coby svůj první samostatný divadelní projekt Müllerův divadelní text Die Schlacht (Bitva, 1979), po němž následovaly inscenace textů Prometheus (1983), Hamlet-stroj (1984) a FatzerMaterial (1985); poslední zmíněná inscenace se odehrála v prostoru údržbářské dílny rakouských drah (Reparaturhalle der Österreichischen Bundesbahnen). Později, po pádu železné opony, kdy se v roce 1992 Heiner Müller stal jedním z pěti ředitelů Berliner Ensemble (z něhož byl samotným Brechtem jako začínající mladý budovatelsky smýšlející básník vyhozen), režíroval zde Josef Szeiler těsně před Müllerovou smrtí jeho Filoktéta (1995).

13 Toto uskupení, které tvořili Matthias Langhoff, Peter Zadek, Fritz Marquardt, Peter Palitzsch a Heiner Müller, vydrželo necelé tři roky (1992-1995). Poté, co se pětičlenné vedení po sporech a neshodách rozpadlo, stanul Heiner Müller ve vedení sám a setrval v něm až do své smrti v prosinci 1995.

14 Slovní obrat Jenseits des Todes je explicitním odkazem na poznámku v Müllerově divadelním textu Popis obrazu (Bildbeschreibung), kde zaznívá mimo jednolité souvětí hlavního textu: „POPIS OBRAZU se dá číst jako plocha přemalující ALKESTIS, která cituje hru Nó KUMASAKA, 11. zpěv Odyssey, Hitchcockovy PTÁKY a Shakespearovu BOUŘI. Text popisuje krajinu z druhé strany smrti. Děj je libovolný, nebot se jeho důsledky staly minulostí, explozí vzpomínky v odumřelé dramatické struktuře“ (MÜLLER 1999: 119). 
níž by byly uvedeny veškeré Müllerovy texty. Akce se měla odehrát v létě 1996, ale vzhledem k Müllerově smrti v prosinci 1995 se projekt nakonec nerealizoval. Idea tohoto projektu je zachycena v publikovaném rozhovoru mezi Josephem Szeilerem, Heinerem Müllerem a Aziou Haas z roku 1992.

HM: Josefe, musíme uzavřít smlouvu. Ku příležitosti mých devadesátých narozenin, až budu mrtvý, vytvořišs show z mých nejdůležitějších textů. Bude trvat celých dvacet čtyři hodin. Přesně tak, jak jsi ř́kal. Ještě si promluvíme o tom, které texty by to měly být. Představuji si, jak by bylo skvělé - nezávisle na mé osobě - kdyby se v rámci jednoho týdne postupně odehrávaly všechny napsané texty jednoho autora.

JS: Možná by se to dalo uspíšit na tvé sedmdesáté narozeniny. Tvojí devadesátky se asi nedožiju, ty určitě. (HAAS 1994: 137)

I přesto, že v případě tohoto příkladu tvůrčí spolupráce Josefa Szeilera a Heinera Müllera nakonec zůstalo pouze u záměru, jedná se o jeden z dokladů toho, jak se Heiner Müller inspiruje metaforou neustále se štěpícího nehierarchizovatelného oddenku a rizomatičnost chápe jako leitmotiv své tvorby. Samozřejmě lze zmíněný záměr chápat i zcela nepostmoderně, tedy v tom smyslu, že inscenované texty jsou sjednoceny osobou jejich autora. Nicméně $\mathrm{v}$ př́ípadě Müllera, který svůj estetický program staví na vzájemném propojení textů prostřednictvím citování, je tato interpretace v tuto chvíli méně zajímavá než ta, že cílem projektu bylo zdůraznit zmíněnou propojenost jednotlivých Müllerových textů v čase a prostoru.

Můžeme si představovat různé, konzervativnější i experimentálnější varianty toho, jak by Josef Szeiler režijně-dramaturgicky k oživení všech Müllerových textů přistoupil. Dobových informací existuje konkrétně k tomuto projektu poskrovnu, nicméně v hrubých obrysech si jej lze představit jako nepřetržitou sedmidenní organickou událost, která by se pravděpodobně odehrávala nikoliv pouze na scéně Berliner Ensemble, ale zasahovala by také do veřejného prostoru mimo divadelní budovu. ${ }^{15}$ Zároveň lze v představě vycházet také ze Szeilerova chápání Müllerových textů jakožto rytmických ploch, které Szeiler uchopuje nikoliv z hlediska jejich obsahu, nýbrž z perspektivy akustického zážitku, jejž při hlasitém čtení vyvolávají. ${ }^{16}$ Představíme-li si takovou „společnou přítomnost“ všech Müllerových textů, těch dramatičtějších i těch přímo divadelních, v ohraničeném čase sto šedesáti osmi hodin, může nám tato představa pomoci právě $\mathrm{k}$ vizualizaci jinak poměrně abstraktní aplikace konceptu rizomatu na jeho dílo: dovoluje nám nahlédnout veškeré Müllerovy texty i výroky jako jeden organismus, v němž lze jednoduše mapovat stále nové a nové souvislosti. Jak se ukáže i na následujícím příkladu, rizoma je konceptem, jehož vlastnosti se lépe vysvětlují

15 V této základní představě vycházím z vyprávění samotného Szeilera, kterého jsem o projektu slyšela vyprávět osobně na jednom ze seminářu během svého zahraničního studijního pobytu na vídeňské univerzitě.

16 Rytmičnosti Müllerova psaní nejen poezie, ale i kvazi prozaických a kvazi dramatický textů si lze všimnout na prríkladu rozhlasové realizace textu Hamlet-stroj z roku 1990 v produkci německé hudební skupiny Einstürzende Neubauten. Dostupné online na https://www.youtube.com/watch?v=0151400OT18\&t=1054s. 
na performativním časoprostorovém materiálu než na statickém artefaktu. Mohou tak totiž vyniknout vzájemné vztahy a provázanost uzlů rizomatu, kterými mohou být texty, teze, politické názory, divadelní tvorba či události z Müllerova života, jejichž souvislost by jinak recipientovi mohla uniknout.

\section{Müller-stroj}

Celé Müllerovo dílo, kam je potřeba zařadit nejen jednotlivé texty, ale i autorem vykonstruovaný obraz sebe samého, je mnohočetností bez jednoty, kterou by v obvyklém př́padě představovala „autorita“ autora. Pro konkrétnější představu této organické mnohočetnosti se lze opřít o projekt rozhlasových dramaturgů Thomase Fritze, Stefana Kanise a Franze Alkena, kteří pro německou rozhlasovou stanici Mitteldeutscher Rundfunk vytvořili multimediální platformu müllerbaukasten.de, ${ }^{17}$ která funguje jako hypertextová sít obrazových, zvukových, audiovizuálních i textových materiálů vybraných z Müllerova režijního i literárního díla. Interaktivně je zde možné doslova projít genezí básně „Herzkranzgefäß“18 (Věnčitá tepna) z roku 1992, která je na webové stránce interaktivně rekonstruována na základě Müllerových osobních zápisků, na lékařském poučení pacienta (Müllera) o srdeční katetrizaci, na telegramu a dalších volných papírech. Mimo to jsou v hypertextu müllerbaukasten ke shlédnutí také například úryvky ze záznamů inscenací Müllerových textů v Müllerově režii, lze si zde poslechnout audionahrávky jeho veřejných čtení, přečíst rozhovory s Müllerem a na jedné ze stránek webu ubíhají jeden za druhým Müllerovy bonmoty vyňaté z jeho mediálních výstupů.

Na jedné z plošin hypertextu, jež pojednává prostřednictvím Müllerových vzájemně se postupně překrývajících manuskriptů zmíněnou genezi básně „Herzkranzgefäß“, si lze povšimnout signifikantního škrtu v názvu podstránky Der Autor Text bei der Arbeit ${ }^{19}$ (Autor Text při práci). Jednou z tvůrčích strategií Heinera Müllera je totiž seberozpuštění subjektu ve vlastním textovém díle - strategie, na kterou bylo odkazováno již v úvodu této studie. Jak bylo řečeno, Heinera Müllera lze tedy prizmatem rizomu chápat jako pouze dočasně jednotící koncept jeho vlastního díla (MATONOHA 2017: 84). U Heinera Müllera se tento jev realizuje hned dvěma způsoby. Za prvé sebemytizací a za druhé vírou v autonomnost umění, které je nezávislé na tom, kdo jej stvořil.

Je nápadné, jak lze téměř každý Müllerův výrok v médiích pokládat za okřídlenou větu, kterou lze dle potřeby v plném znění citovat (což se při reflexi Müllera také často děje). Gaetano Biccari ve své studii na téma Müllerova sebeinscenování v natáčených

17 Müller Baukasten [online]. Dostupné online na: https://www.muellerbaukasten.de. Pro porozumění tomu, na jakých principech rizoma funguje, doporučuji čtenáři, aby se s touto platformou seznámil. Např́iklad metafora mapování, s rizomatem neodlučitelně spjatá, nabývá v tomto, byt virtuálním, časoprostorovém ztvárnění mnohem jasnějších rysů.

18 Báseň odráží Müllerovu skutečnou lékařskou diagnózu (MÜLLER 1998a: 249).

19 Der Autor Text bei der Arbeit. Müller Baukasten [online]. Leipzig: MITTELDEUTSCHER RUNDFUNK [cit. 4. 5. 2020]. Dostupné online na https://www.muellerbaukasten.de/heiner-mueller/der-autor-text-bei-der-arbeit/. 
rozhovorech píše, že „situace rozhovoru pro něj znamenala ideální herní pole inscenování sebe sama i svého díla, které osciluje mezi autenticitou a fikcí" (BICCARI 2009: 216). Konstanty Já ani Autor nejsou pro Müllera autoritativními hodnotami, nýbrž pouze hlasy v polyfonním diskurzu, který pochází z prehistorie člověka a který Müller nazývá „dialogem s mrtvými“20 (BICCARI 2009: 217). Symptomatická je v tomto ohledu i Müllerova sebemytizace, která se projevuje mimo jiné v autobiografii Krieg ohne Schlacht. Leben in zwei Diktaturen (Válka bez bitvy. Život ve dvou diktaturách, 1992), o níž filosof a estetik Norbert Otto Eke tvrdí, že „není biografií, ačkoliv na první pohled působí jako detailní zápis jeho života; [...] vzpomínky kladou přes skutečnosti z Müllerova soukromého života více clon, než aby bylo vůbec možné prodrat se skrze tuto rekonstrukci modelování vlastní identity až k osobnosti samé [...]“ (LEHMANN a PRIMAVESI 2003: 1). Paradoxem je, že Heiner Müller tematizoval události ze svého života ve svém básnickém díle poměrně hojně. $\mathrm{V}$ jeho případě se však jedná o mytizaci dané události a její proměnu v umělecké dílo, které po této proměně již nemá nic společného s osobním prožitkem ani sdílením zkušenosti za účelem psychologicko-emocionálního napojení na čtenáře. ${ }^{21}$

Na vztahu uměleckého textu a konkrétní reálné události, s níž je Müller jako osoba spojen, se také ukazuje popření principu reprezentace, což je druhou vytčenou vlastností rizomatu, která je pro Müllerovo dílo, jak pro divadelní texty, tak pro poezii a prózu, př́iznačná. Určitá báseň či část divadelního textu tak nezrcadlí realitu, ale je její součástí v rámci rizomatických propojení, jimiž do reality vstupuje, intervenuje v ní a zároveň je jí proměňována. Lze to pozorovat například na zmíněné básni „Herzkranzgefäß“, která patrně - soudě podle geneze básně, jež ukazuje verše, které se ve finální verzi textu neobjevují, - úzce souvisí s Müllerovým onemocněním rakovinou, na něž posléze v roce 1995 také zemřel. Čtení básně se mění, chápeme-li ji v napětí dichotomie „fikce-autenticita“ ve vztahu k Müllerovu onemocnění, jež se v ní stává svébytným uměleckým motivem. V závislosti na tom, jestli víme či nevíme, že báseň nepř́ímo odkazuje na autorovu smrt, je možné ji recipovat dvojím způsobem. Dílo je konstruováno jako vlastní fikční svět a nejde primárně o zobrazení reálného prožitku, ačkoliv je explicitně tematizován.

Samozřejmě že z praktického hlediska je Müller stále tvůrcem a původcem svých textů, jde ale o to, že sám sebe - nejen v duchu koncepce rizomatu, ale i jiných poststrukturalistických teorií - konstruuje, (právě) s plným vědomím sebe sama coby autorského

20 Pod pojmem „dialog s mrtvými“ chápe Müller princip intertextuality, která se stává estetickým programem. Viz jeho vlastní definici: „Život budoucích generací lze vidět i v minulosti. [...] Každý nový text se nějakým způsobem vztahuje k množství starších textů jiných autorů a mění pohled na ně. To, jak zacházím se starými látkami a texty, je také zacházení s tím, co teprve nastane. To je, chcete-li, dialog s mrtvými“ (LEHMANN 2003: 47).

$21 \mathrm{O}$ tomto Müllerově postoji k realitě rozpouštěné do uměleckého vyjádření svědčí úryvek z rozhovoru z roku 1987 publikovaného v časopise Zeit: „Ve vašem textu Hamlet-stroj je Ofélie sebevražedkyní, která se, jak sama říká, přestane zabíjet. Biografickou souvislost s vámi si nelze odmyslet. - MÜLLER: A jaký to má význam? Sebevražda mé ženy mě přeci nijak nevysvětluje. Ve válce ji to třikrát zasypalo. Její rodiče byli zavražděni. Vyproštovala jejich těla po částech z protiletadlového krytu a ty pak odnesla na hřbitov. Z toho se u ní rozvinulo válečné trauma. A nezbavila se ho. Pokud něco takového použiji jako motiv, stane se to literaturou a existuje to už jen v těchto textech. Nic dalšího na tom není zajímavé. To, že se dnes místo čtení textů považuje za zajímavější to, co se za nimi skrývá, dokazuje hluboký kulturní úpadek.“ (MÜLLER 1987) 
subjektu, a záměrně se jako jednotící autorita do svých textů rozpustí a prostoupí je, takže ve smyslu Foucaulta utvoří diskurz, ve kterém standartní mocenské síly textové produkce nemají místo. Zároveň tak Müller dostojí jednomu ze svých filosoficko-estetických tvrzení, že „text je chytřejší než autor“ (SCHNEIDER 2014: 19), ve kterém lze najít nápadnou paralelu s Barthesovým konceptem smrti autora, jenž jej pojímá jako entitu bez historie, biografie a psychologie (BARTHES a JIRSA 2006: 77).

Tvář s ostře řezanými rysy, brýle s výraznými černými obroučkami, doutník a whisky jsou Müllerovou neměnnou umělou maskou rizomatu Heiner Müller.

\section{Text proti divadlu a laboratoř sociální fantazie}

Heiner Müller je básníkem a divadelníkem, který programově nepřijímá instituci divadla a divadelní tvorbu v její stávající podobě. Divadlo nahlíží z principu kriticky, a tudíž i jeho vlastní tvorbu provází sklon k neustálému promýšlení starých či stávajících forem a k hledání inovací. Nejde o to, že by anachronismy nahrazoval něčím radikálně novým, ale o princip filosofického uvažování nad divadlem jako stále se proměňující sociálně konstruovanou institucí, která, aby mohla reagovat na aktuální potřeby společnosti, musí být tvárná. ${ }^{22}$ Jeho koncepce nové dramatiky a nového divadla se tedy nezakládá na snaze nastolit novou, aktuálnější estetickou ideologii, ale na vizi „filosofického“ dramatu promýšlení, myšlenkové hry a vzpomínavého vcitování a divadla jako prostoru společenské kreativity, kterou lze chápat jako dostatek představivosti k tomu konstruovat nový, lepší společenský systém. Nebot právě tento př́stup je na estetické úrovni tím „krokem do absolutní temnoty, do neznáma, z něhož možná vyvstanou nové divadelní formy nebo i nový způsob, jak zacházet s divadelním prostorem“ (Müller in EKE 1999: 52-53)

Divadelní text Popis obrazu (Bildbeschreibung, 1984) představuje textovou krajinu (Textlandschaft nebo Landscapeplay), ${ }^{23}$ nečleněnou textovou plochu sestávající z jediného souvětí, $\mathrm{k}$ němuž náleží jedna krátká poznámka. V Müllerově tvorbě představuje vrcholný a určitým způsobem i hraniční bod jeho postdramatických experimentů. ${ }^{24} \mathrm{Na}$ tomto místě na Popis obrazu odkazuji, nebot svou formou jediného souvětí odpovídá neredukovatelné rizomatické heterogennosti. Nepodléhá jednotícímu sémantickému významu, nebot text vyobrazuje tableau vivant, snovou, surrealistickou situaci v zasta-

22 „Realita se dá vidět jen tehdy, pokud je rozložená na kusy, na segmenty. Pokud každého diváka toto pohne $\mathrm{k}$ tomu, aby kusy znovu poskládal, stane se z ní jeho vlastní realita, také ve spojení s jeho vlastní snovou realitou. To by mohlo být divadlo budoucnosti.“ (Müller in SCHNEIDER 2014: 7)

23 Je známým faktem, že se Heiner Müller inspiroval mimo jiné i tvorbou Gertrude Stein. Tomu, jak se vizualita a principy výtvarného umění promítají do principů psaní Heinera Müllera, se věnuje Wolfgang Storch v hesle „Die bildenden Künste“ v Lehmannově a Primavesiho příručce Heiner Müller Handbuch. „V jeho technikách, ostrých řezech a skocích, v kladení obrazů a metafor lze však vliv výtvarného umění stále rozpoznat. Píše obrazy, které chtějí být slyšet a vidět“ (STORCH 2003: 113).

24 Hanna Klessinger ve své monografii Postdramatik: Transformationen des epischen Theaters, v níž stopuje Müllerovu tvorbu chronologicky, poukazuje na to, že v pětici lehrstücků Silnice na Volokolamsk I-V (1985/6) se Müller opět do určité míry navrací k některým strategiím dramatické formy (KLESSINGER 2015: 30). 
vení, která implicitně pojednává vztah mezi obrazem a pozorovatelem (který je v textu vyjádřen jako oko). Neuchopitelná heterogennost a nepřevoditelnost na jednotící systém znamená v př́ípadě divadelního textu určeného ke scénické realizaci také nutný dialog inscenátora s textem. Protože není jednoduše hierarchizovatelný a chybí mu sémantická jednota, neexistuje jeden jediný způsob, jak jej vyložit, a tudíž vyžaduje od inscenátora tvưrčí invenci. ${ }^{25}$

\section{Intertextualita jako estetický program}

Na příkladu Müllerovy básně „Notiz 409“ (Poznámka 409) vznikl v letech 1996/97 na Humboldtově univerzitě v Berlíně experimentální literárněvědný projekt, jehož cílem bylo pomocí hypertextového softwaru vytvořit vizualizaci intertextuality. ${ }^{26}$ Prostřednictvím odkazů obsažených v konkrétních slovních obratech či celých verších, které jsou zároveň citací jiných Müllerových textı̊, se lze na této webové stránce prokliknout na konkrétní citovaný (pre)text. Müller nechává jednotlivá slova, verše, drobnější motivy v obměnách či nezměněné, celé textové pasáže nebo myšlenkové koncepty migrovat např́ič svým dílem z divadelního textu do básně či do mediálního výroku, ${ }^{27}$ nebot některé poetické sekvence lze použít jako teoretické objasnění určité roviny jeho poetiky. Díky projektu Notiz 409 čtenář může snadno zjistit, s jakými dalšími texty, at̉ už texty jiných autorů či Müllerovými, báseň „Notiz 409“ souvisí.

Zřejmě tím nejzásadnějším, co aplikace konceptu rizomatu na tvorbu a dílo Heinera Müllera přináší, je možnost chápat jeho jednotlivé texty ve vzájemných souvislostech. Müller své dílo konstruuje tak, že nechává texty, bez ohledu na jejich formu, aby se vzájemně doslovovaly. - Pokud je autocitace doslovná, prozrazuje to autor formálním odlišením daného textového úseku prostřednictvím verzálek; ${ }^{28}$ některá opakování motivů

25 K tomu se Müller vyjadřuje takto: „V zásadě si myslím, že literatura je od toho, aby divadlu kladla odpor. Jen pokud je text neinscenovatelný tak, jak je divadlo uzpůsobené, může být pro divadlo produktivní nebo zajímavý" (SCHNEIDER 2014: 31-32).

26 „Cílem tohoto projektu bylo propojit pojem intertextuality s možnostmi hypertextového softwaru. To znamená, že texty citované v Müllerově básni „Poznámka 409‘ lze ihned rozkrýt, čímž vychází najevo intertextuální vztahy mezi citovanými texty, přesněji řečeno textovými pasážemi. Ukázalo se také, že Müllerovo ,textové universum“ nelze zmapovat do ,posledního písmene‘." Dostupné online na https://web.archive.org/ web/20080611153122/http://www2.hu-berlin.de/literatur/mitarbeiter/hoernigk/GNPRESS/HOMELESS. HTM [cit. 4. 5. 2020].

27 Za všechny zatím nenalezené otisky uměleckých textů do výpovědí v rozhovorech dokládám tuto Müllerovu tendenci na př́kladu motivu ohrožujicí baletni gramatiky z básně „Das Blut ist im Schuh oder das Rätsel der Freiheit“ (Krev je v botě aneb hádanka svobody) z roku 1981, věnované německé choreografce Pině Bausch. Vzpoura proti baletni gramatice je totiž přesně onen důvod, proč Müllera fascinuje tvorba Piny Bausch a jejího souboru Tanztheater Wuppertal.

28 Např́ílad verš „War ich ein Jäger, von Wölfen gejagt, mit Wölfen allein [Byl jsem lovcem, vlky uloven, s vlky sám]“ z básně „Kindheit“ (Dětství) se objeví v plném znění i v divadelním textu Todesanzeige (Úmrtní oznámení), ovšem ve verzálkách a bez interpunkce: „WAR ICH EIN JÄGER VON WÖLFEN GEJAGT MIT WÖLFEN ALLEIN [BYL JSEM LOVCEM VLKY ULOVEN S VLKY OSAMOCEN]“. Na tomto konkrétním př́íkladu se ukazuje, v čem může být schopnost texty v Müllerově díle usouvztažňovat užitečná. Daný verš v podobě bez interpunkce lze totiž chápat jako hru se syntaxí, která nabízí dvě možnosti čtení: bud' ve znění 
nechává $\mathrm{v}$ textu na první pohled neurčitelná, a citaci tak rozpozná jen čtenář, který je obeznámen s danými zdrojovými texty. ${ }^{29}$ Jelikož se nejedná o ojedinělé případy citování, Müllerovo dílo je ve svém důsledku utkané do struktury rizomatu takovým způsobem, že do něj lze vstupovat z jakékoliv strany, objevovat stále nové, navzájem určitým způsobem související skupiny textů a ve smyslu rizomatického myšlení tyto cesty zpětně mapovat.

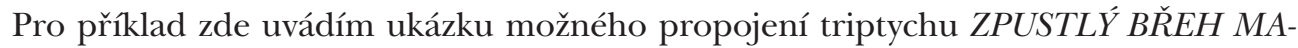
TERIÁL MÉDEA KRAJINA S ARGONAUTY (VERKOMMENES UFER MEDEAMATERIAL LANDSCHAFT MIT ARGONAUTEN, 1982) a staršího divadelního textu Hamlet-stroj (Hamletmaschine, 1977) prostřednictvím obrazu sypké látky na rtech, který se v textech objevuje v obměnách jako popel a sníh.

\section{Hamlet-stroj: \\ „AUF DEN LIPPEN SCHNEE [NA RTECH SNÍH]“}

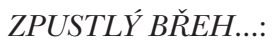

„Die Asche deiner Küsse auf den Lippen [Popel tvých polibků na rtech]“

Jistě lze tento princip vzájemného propojování vlastních textů chápat také jako autorskou manýru, nicméně je důležité, že v tomto konkrétním případě jej není užito jen pro forma, ale že v něm lze spatřovat ten samý obraz ženy-revolucionářky (Medea-Ofélie), který se neobjevuje jen v triptychu o Médeie a v divadelním textu Hamlet-stroj, ale i v jiných Müllerových textech. ${ }^{30}$

Z předchozího lze usuzovat, že při interpretaci Müllerových pozdních divadelních textů, které jsou co do srozumitelnosti poměrně náročné právě kvůli své extrémní poetičnosti v kombinaci s programovou rizomatičností, může být nápomocné vnímat je ve vzájemných kontextech a mapovat jejich souvislosti.

\section{Meze konceptu a výhled}

Pojem rizoma, jímž Deleuze a Guattari pojmenovali nehierarchický a multiplicitní způsob přemýšlení a navrhli tak alternativu dualistického logocentrického myšlenkového schématu, není v českém kontextu neznámý. Je patrné, že divadelní věda si jej, podobně jako jiné poststrukturalistické koncepty, osvojuje pomaleji než například literární věda nebo mediální studia, nebot v teatrologických textech se zatím objevuje spíše ojediněle

\footnotetext{
daném interpunkcí, nebo ve smyslu „BYL JSEM LOVEC VLKŮ ULOVEN S VLKY SÁM“. Rodilý mluvčí může vnímat obě možnosti čtení v textu zároveň, ovšem u překladu už by byl problém, jak verš interpretovat, aby byla tato jeho polysémantičnost zachována.

29 Principy citování pojednává mimo jiné Katharina Keim ve své disertační práci Theatralität in den späten Dramen Heiner Müllers (1998).

30 Podobný ženský archetyp obsahuje např. i „postava“ Dashy v textu Cement (Zement).
} 
a nelze jej řadit do oblasti dominantního diskurzu disciplíny. ${ }^{31}$ Osobně se však domnívám, že rizoma může vedle jiných poststrukturalistických i novějších konceptů obstát minimálně ve snaze přiblížit se některým principům divadelní, taneční a dramatické tvorby, pro něž se v českém divadelním kontextu plošně ujal výraz Hans-Thiese Lehmanna „postdramatický“. Vezmeme-li totiž v potaz fakt, že i když se adjektivum postdramatický užívá nejen v české teatrologii jako terminus technicus, je pojem postdramatické divadlo do velké míry abstraktní a obecný. Lehmann ve svém eseji totiž nevymezuje materiál, kterým se zabývá, nenabízí v souvislosti se zaváděným pojmem žádný koherentní terminologický a metodologický aparát, který by jej umožnil vnímat a aplikovat jako stabilizovaný analytický nástroj, a ani to nebylo jeho cílem (srov. LEHMANN 2007: 15-18). Spíše se pokusil z vlastní zkušenosti pozitivně vymezit a načrtnout rysy paradigmatu nového divadla, do něhož radí vedle choreografické tvorby a psaní pro divadlo také divadelní praxi, a motivovat tak k zevrubnějším, detailnějším analýzám tohoto, jak sám piše, často složitého divadla. ${ }^{32}$ Nebylo předmětem této studie vést polemiku o tom, zda a jak používat termín postdramatické divadlo, ${ }^{33}$ ale využít konceptu rizomatu k odhalení některých tvůrčích principů Heinera Müllera, na něž může být pojem „postdramatický“ rovněž použit - a také často bývá.

Smysl konceptu rizomatu tkví především v tom, že nabízí způsob, jak pochopit principiální nelogocentričnost, nehierarchičnost, programovou intertextuálnost a sémantickou nejednoznačnost vedoucí k interpretační otevřenosti Müllerových (nejen) pozdních textů, ale i jeho př́stupu k tvorbě obecně. Rizoma však samo o sobě neposkytuje dostatečný pojmový aparát, aby bylo možné se jeho prostřednictvím analyticky vypořádat s jeho pozdními divadelními texty, u nichž, ačkoliv jsou určeny k divadelnímu ztvárnění, Müller, ze svého přesvědčení o nutnosti podněcovat divadelním textem uměleckou inovaci, tradiční model dramatu úplně opustil. Německá překladatelka, dramaturgyně a autorka disertační práce Der nicht mehr dramatische Theatertext a zevrubné definice pojmu divadelni text, Gerda Poschmann, jejíz práce se v českém teatrologickém prostoru stále silněji etabluje, ve své dramaturgické analýze navrhuje pokusit se u textů, které zachází s dramatickou formou kriticky či ji úplně popírají, nalézt klíč k jejich originální vnitřní teatralitě. ${ }^{34}$

31 Ve své habilitační přednášce s názvem „Stáhnout se do kořenů a nalézt živé slovo. O existenciálních předpokladech dialogu uměním" se o koncept rizomatického myšlení v souvislosti s radikalitou uměleckého vyjádření opírá teatrolog a religionista Jan Motal (2018). Tereza Turzíková využívá různé koncepty Gillese Deleuze a Félixe Guattariho, mezi nimi i rizoma, k analýze vybraných inscenací divadla D’epog (TURZÍKOVÁ 2019).

32 Jeho spis má, podle jeho vlastních slov, „slúžit na ,pojmové zachytenie“ a ,verbalizovanie skúsenosti“ s týmto často ,zložitým“ divadlom súčasnosti, a tým podnietit jeho vnímanie a diskusiu o ňom“ (LEHMANN 2007: 16).

33 Detailně se problematice této Lehmannovy monografie věnuje mj. Lenka Jungmannová (2018).

34 Přestože obsáhlá studie Gerdy Poschmann zatím není přeložena do češtiny, její koncepci využila a poměrně detailně i za pomoci překladů určitých částí osvětlila teatroložka Jitka Pavlišová ve své disertaci Vývojové tendence rakouské dramatiky po roce 2000 (PAVLIŠOVÁ 2012). Velké pozornosti se reflexi Poschmann dostalo i v nedávno vydané sbírce studií Divadlo a text (MERENUS, MIKULOVÁ a ŠOTKOVSKÁ 2019). 
Každý divadelní text, u něhož není možné určit klasické hierarchie vlastní uzavřené dramatické formě postavené na principu reprezentace, což je i případ pozdních Müllerových textů, nabízí množství nejrůznějších uchopení a záleží na každém, které z nich upřednostní. Nejde přitom o svévoli obsaženou ve způsobu konstrukce těchto textů, ale o vlastní logiku, kterou nabízejí a kterou je třeba odkrýt, abychom se jim mohli přiblížit. Zmínka o konceptu divadelního textu Gerdy Poschmann budiž pouze výhledem na analytický nástroj, který může být v případě divadelních textů, které nejsou uchopitelné prostřednictvím postupů tradiční analýzy dramatu, produktivní.

\section{Bibliografie}

ARNOLD, Heinz Ludwig (ed.). 1982. Text + Kritik: Heiner Müller. München: Grimm + Bleicher, 1982.

ARNOLD, Heinz Ludwig (ed.). 1997. Text + Kritik: Heiner Müller. München: Grimm + Bleicher, 1997.

BARTHES, Roland a Tomáš JIRSA. 2006. Smrt autora. Aluze 10 (2006): 3: 75-77.

BICCARI, Gaetano. 2009. Heiner Müller Fernsehinterviews: Performance - Oralität - Autobiographie. In Theo Girshausen. Theatrographie: Heiner Müller Theater der Schrift. Berlin: vorwerk8, 2009: 215-226.

DELEUZE, Gilles a Félix GUATTARI. 2010. Tisic plošin. Praha: Herrmann\&synové, 2010.

EKE, Norbert Otto. 1999. Heiner Müller. Stuttgart: Reclam, 1999.

HAAS, Aziza. 1994. Gespräch mit Heiner Müller und Josef Szeiler. 6. 5. 1992: Theater ist das einzige, was überhaupt noch geht. Maske und Kothurn. Internationale Beiträge zur Theaterwissenschaft (36) 1994: 1-4: 105-144.

HAUER, Tomáš. 2002. S/krze postmoderni teorie. Praha: Karolinum, 2002.

JOBERTOVÁ, Daniela, Zuzana AUGUSTOVÁ a Jan JIŘÍK. 2017. Horizonty evropského dramatu: Současný divadelni text mezi dramatickými a postdramatickými tendencemi. Praha: NAMU, 2017.

JUNGMANNOVÁ, Lenka. 2018. Postdramatické divadlo jako pojem aneb Postteatrologie. Divadelni revue 29 (2018): 1: 52-59.

KEIM, Katharina. 1998. Theatralität in den späten Dramen Heiner Müllers. Tübingen: Niemeyer, 1998.

KLESSINGER, Hanna. 2015. Postdramatik: Transformationen des epischen Theaters bei Peter Handke, Heiner Müller, Elfriede Jelinek und Rainald Goetz. Berlin: De Gruyter, 2015.

LEHMANN, Hans-Thies. 1982. Raum-Zeit. In Heinz Ludwig Arnold (ed.). Text + Kritik: Zeitschrift für Literatur. München: edition text + kritik, 1982: 71-81.

LEHMANN, Hans-Thies. 2007. Postdramatické divadlo. Bratislava: Divadelní ústav, 2007.

LEHMANN, Hans-Thies a Patrick PRIMAVESI (edd.). 2003. Heiner Müller. Handbuch. Leben-Werk-Wirkung. Stuttgart: J. B. Metzler, 2003.

MATONOHA, Jan. 2017. Za (de)konstruktivismem: Kritické koncepty (post)-poststrukturálni literární teorie. Praha: Academia, 2017.

MERENUS, Aleš, Iva MIKULOVÁ a Jitka ŠOTKOVSKÁ. 2019. Text a divadlo. Praha: Academia, 2019. 
MOTAL, Jan. 2018. Stáhnout se do kořenů a nalézt živé slovo. In Jan Motal [online]. [cit. 202005-04]. Dostupné online na https://www.janmotal.cz/index.php/prednaska/.

MÜLLER, Andre. 1987. Die Dichter müssen dumm sein: Ein Gespräch mit dem Schriftsteller Heiner Müller. Zeit (1987): 34.

MÜLLER, Heiner. 1982. Příkaz a jiné texty. Překl. Josef Balvín. Praha: Dilia, 1982.

MÜLLER, Heiner. 1998a. Werke 1. Die Gedichte. Frankfurt am Main: Suhrkamp Verlag, 1998.

MÜLLER, Heiner. 1998b. Pověreni [Tř́ hry]. Překl. K. R. Jilská. Praha: Prostor, 1998.

MÜLLER, Heiner. 1999. Werke 2. Die Prosa. Frankfurt am Main: Suhrkamp Verlag, 1999.

PFISTER, Manfred. 2000. Drama. Theorie und Analyse. München: Wilhelm Fink Verlag, 2000.

POSCHMANN, Gerta. 1997. Der nicht mehr dramatische Theatertext. Tübingen: Max Niemeyer Verlag, 1997.

SCHNEIDER, Detlev (ed.). 2014. Heiner Müller - Theater ist ein kontrollierter Wahnsinn. Berlin: Alexander Verlag Berlin, 2014.

STORCH, Wolfgang. 2003. Übergreifende Aspekte des Werks. Die Bildenden Künste. In Hans-Thies Lehmann a Patrick Primavesi (edd.). Heiner Müller. Handbuch. Leben-Werk-Wirkung. Stuttgart: J. B. Metzler, 2003: 113-123.

TURZÍKOVÁ, Tereza. 2019. Rhizomatika: D‘epog a limity divadelního aparátu. Brno: 2019. Bakalářská diplomová práce. Masarykova univerzita, Katedra divadelních studií, nepubl.

Müller Baukasten [online]. Leipzig: MITTELDEUTSCHER RUNDFUNK [cit. 4. 5. 2020]. Dostupné online na https://www.muellerbaukasten.de.

Müller Baukasten: Der Autor Text bei der Arbeit [online]. Leipzig: MITTELDEUTSCHER RUNDFUNK [cit. 4. 5. 2020]. Dostupné online na https://www.muellerbaukasten.de/heiner-mueller/der-autor-text-bei-der-arbeit/.

Notiz 409. 1996/7. Dostupné online na https://web.archive.org/web/20080611153122/http:// www2.hu-berlin.de/literatur/mitarbeiter/hoernigk/GNPRESS/HOMELESS.HTM.

Einstürzende Neubauten. 1990. Hamletmaschine [cit. 2020-05-04]. Dostupné online na https:// www.youtube.com/watch? $\mathrm{v}=0151400 \mathrm{OTl} \& \& \mathrm{t}=1054 \mathrm{~s}$. 


\section{Mgr. Barbora Liška}

Katedra divadelních a filmových studií,

Filozofická fakulta Univerzity Palackého v Olomouci,

Univerzitní 3, 77900 Olomouc

Liska.barbor@gmail.com

Barbora Liška (roz. Kašparová) absolvovala studium divadelní vědy a překladatelství němčiny na Masarykově univerzitě. Ve svém doktorském studiu, které nastoupila na Univerzitě Palackého v Olomouci, se věnuje výzkumu dramaturgie těla a pohybu, pro který čerpá zejména z poznatků německé taneční vědy. Je spoluzakladatelkou a redaktorkou brněnského časopisu CEDIT - kontexty a přesahy Centra experimentálního divadla.

Barbora Liška (maiden name Kašparová) majored in theatrology and German translation at Masaryk University. In her PhD research at Palacký University Olomouc, she focuses on body and movement dramaturgy, finding inspiration in German dance studies. She is co-founder and editor of a journal named CEDIT - Contexts and Overlaps published by the Experimental Theatre Center, Brno. 